\title{
NASIONALISASI PERUSAHAAN PENANAMAN MODAL ASING DI INDONESIA
}

\author{
I Gusti Ag.A.Mas Triwulandari(1), I Nyoman Budiana ${ }^{(2)}$ \\ agungmas84@gmail.com; nyoman_ny@yahoo.com \\ Undiknas University, Denpasar, Bali
}

\begin{abstract}
The purpose of this study is to understand the basis of the government action to nationalize foreign investment companies and legal protection of investors as a result of these nationalization actions. The research method used is normative juridical or library research related to normative substance of law, to find truth based on logic of science regarded from normative side by way of researching bibliography or secondary data consisting of primary law material, secondary law material and tertiary law material. The result of the research shows that the basic of nationalization action by the government underlying are due to economic inequality, where foreign capital companies start to dominate the main sectors in the national economy, and the other thing is the politics of nationalization law. Legal protection of investors is focused on preventive law protection, in which investors are given the opportunity to file an objection (inspraak) before a government decision in the definitive form of nationalization action.

Keywords: Nationalization, Foreign Investment Company, Foreign Direct Investment
\end{abstract}

\begin{abstract}
ABSTRAK
Penelitian ini bertujuan untuk mengetahui hal-hal yang mendasari pemerintah melakukan tindakan nasionalisasi perusahaan penanaman modal asing serta perlindungan hukum terhadap investor sebagai akibat tindakan nasionalisasi tersebut. Metode penelitian yang digunakan adalah yuridis normatif atau penelitian kepustakaan yang berkaitan dengan substansi hukum yang bersifat normatif, untuk menemukan kebenaran berdasarkan logika keilmuan dipandang dari sisi normatifnya dengan cara meneliti bahan pustaka atau data sekunder yang terdiri dari bahan hukum primer, bahan hukum sekunder dan bahan hukum tersier. Hasil penelitian diperoleh bahwa hal-hal yang mendasari pemerintah melakukan tindakan nasionalisasi adalah karena terjadinya ketimpangan ekonomi, dimana perusahaan modal asing mulai mendominasi sektor-sektor utama dalam perekonomian nasional, dan hal lain yang mendasari adalah politik hukum nasionalisasi. Tindakan nasionalisasi merupakan perbuatan hukum yang bersifat politis yang dalam praktek hukum kenegaraan sering disebut dengan politik hukum. Kebijakan ini diambil dengan maksud agar negaranegara tujuan investasi dapat membangun kembali struktur perekonomiannya akibat dominasi modal asing. Perlindungan hukum terhadap investor dititikberatkan pada perlindungan hukum preventif, dimana investor diberikan kesempatan untuk mengajukan keberatan (inspraak) sebelum keputusan pemerintah dalam bentuk definitif terkait tindakan nasionalisasi.
\end{abstract}

Kata Kunci: Nasionalisasi, Perusahaan PMA, Foreign Direct Investment 


\section{PENDAHULUAN}

Setiap Negara selalu berusaha meningkatkan pembangunan, kesejahteraan dan kemakmuran rakyatnya. Usaha tersebut dilakukan dengan berbagai cara yang berbeda antara satu Negara dengan Negara lainnya. Salah satu usaha yang selalu dilakukan oleh Negara adalah menarik sebanyak mungkin investasi asing masuk ke Negaranya. ${ }^{1}$ Menarik investasi masuk sebanyak mungkin ke dalam suatu Negara didasarkan pada suatu mitos yang menyatakan bahwa untuk menjadi suatu Negara yang makmur, pembangunan nasional harus diarahkan ke bidang industri. Sebagai jalan untuk mengarah kesana, sejak awal negara-negara tersebut dihadapkan kepada permasalahan minimnya modal dan teknologi yang merupakan elemen dasar dalam menuju industrialisasi. Jalan yang ditempuh untuk mengatasi masalah tersebut adalah mengundang masuknya modal asing dari Negara-negara maju ke dalam negeri. ${ }^{2}$ Masuknya modal asing bagi perekonomian Indonesia merupakan tuntutan keadaan baik ekonomi maupun politik Indonesia. Alternatif perhimpunan dana pembangunan perekonomian Indonesia melalui investasi modal secara langsung jauh lebih baik dibandingkan dengan penarikan dana internasional lainnya seperti pinjaman luar negeri. ${ }^{3}$

Filosofi kebijakan PMA adalah bahwa modal asing diperlukan guna melengkapi modal dalam negeri yang tidak cukup kuat memutar roda perekonomian Negara. Tetapi manakala modal asing itu kemudian mendominasi perekonomian nasional, dan menyebabkan ketergantungan ekonomi, sering timbul sikap permusuhan terhadap PMA. Sikap tidak bersahabat ini dapat diwujudkan dalam keputusan politik untuk menasionalisasikan atau mengambil alih modal asing.

Dijelaskan dalam Pasal 7 ayat (1) UU No.25 Tahun 2007 tentang Penanaman Modal, berkaitan dengan kewenangan Pemerintah untuk tidak

1 Ahmad Yulianto, 2003, Peranan Multilateral Investment Guarantee Agency (MIGA) Dalam Kegiatan Investasi, Jurnal Hukum Bisnis, Vol. 22, No. 5, h. 39

2 Ridwan Khairandy, 2003, Peranan Perusahaan Penanaman Modal Asing Joint Venture dalam Ahli Teknologi di Indonesia, Jurnal Hukum Bisnis, Vol. 22, No. 5 , h. 51

3 Yulianto Syahyu, 2003, Pertumbuhan Investasi Asing di Kepulauan Batam: Antara Dualisme Kepemimpinan dan Ketidakpastian Hukum, Jurnal Hukum Bisnis, Vol. 22, No. 5, h. 46 
akan melakukan tindakan nasionalisasi atau pengambilalihan hak kepemilikan penanam modal, kecuali dengan undang-undang. Pencatuman kata "kecuali dengan undang-undang", ditemukan adanya kekaburan norma (vague van normen) yang menimbulkan multitafsir, di mana dapat diartikan tindakan nasionalisasi bisa saja dilakukan oleh pemerintah Indonesia, namun tidak diberikan kepastian hukum tentang dalam hal apa tindakan nasionalisasi tersebut bisa dilakukan oleh pemerintah. Penjabaran tersebut akan ditelaah kembali oleh penulis dalam hal apa tindakan nasionalisasi dapat dilakukan oleh pemerintah dan terhadap perlindungan hukum bagi investor dalam penanaman modal asing.

\section{TINJAUAN PUSTAKA}

\section{Pengertian Nasionalisasi}

Nasionalisasi sering disamakan dengan konfikasi dan onteigening dan pencabutan hak. Istilah nasionalisasi paling tidak mencakup tiga pengertian "Konfiskasi", "Onteigening" dan "Pencabutan Hak". L. Erades memberikan arti nasionalisasi, yakni suatu peraturan dengan mana pihak penguasa memaksakan semua atau segolongan tertentu untuk menerima (dwingt te godegen), bahwa hak- hak mereka atas semua atau beberapa macam benda tertentu beralih kepada Negara. Dengan demikian nasionalisasi adalah suatu cara peralihan hak dari pihak partekelir kepada negara secara paksa. ${ }^{4}$

Nasionalisasi dipandang sebagai "Species" dari "Genus" pencabutan hak dan Onteigening. Berkaitan dengan ketentuan di atas berarti setiap ada pencabutan hak dan onteigening pada prinsipnya harus diikuti dengan "ganti rugi". Sementara itu jika tidak disertai dengan ganti rugi maka dia dapat disebut dengan "konfiskasi". Konfiskasi ini mirip dengan pencabutan hak (semacam onteigening), tetapi dengan corak khusus tanpa ganti rugi. ${ }^{5}$

4 Investopedia, "Nationalization", URL:

http://www.investopedia.com/terms/n/nationalization.asp, diakses pada tanggal 16 Agustus 2017.

${ }_{5}$ Gouw Giok Siong, 1960, Segi-Segi Hukum Internasional pada Nasionalisasi di Indonesia, Penerbitan Universitas, Jakarta,h. 6 dikutip dari L. Erades, 1954. Het rechseffecct van nationaliteit maatregellen genomen door vreemde staten, Mededelingen van de Nederlandse Vereniging voor International recht, Nederland, h. 32. 
Istilah nasionalisasi termasuk didalamnya "expropriation" atau "Confiscatie". Istilah nasionaliasi ini diartikan bahwa suatu perusahaan menjadi milik negara. Perusahaan bersangkutan menjadi "a nation affair". Dalam hal nasionalisasi yang menjadikan objeknya perusahaanperusahaan. Kollewijn mengemukakan pendapatnya bahwa, "There is said to be nationalisation principally if an expropriation forms part a more or less extensive reform of the social or economie structure of a country", sedangkan Gouw Giok Siong dengan mengutip pendapat Wortley menegaskan bahwa "nationalitation is not a term of art", tetapi digunakan untuk menunjuk pada expropriation in the pursuance of some national enterprises, or to strengthen, a nationally controlled industry. Nationalization differ in its scope and extent rather than in its judicial nature from other types of expropriation ${ }^{6}$

\section{Tujuan Dan Manfaat Nasionalisasi}

Apabila dikaji difinisi diatas, ada dua manfaat dari konsep Nasionalisasi:

a. Mendapatkan keuntungan; dan iscep:

b. Pengalihan kontrol terhadap jalannya perusahaan.

Melihat dari pengertian diatas dari tindakan nasionalisasi yang dilakukan oleh Pemerintah Indonesia, kita dapat menarik tujuan dari penyelenggaraan Nasionalisasi terhadap Perusahaan Penanaman Modal Asing, antara lain:

a. Meningkatkan ekonomi nasional; iscepi

b. Menyelamatkan Penanam Modal Dalam Negeri; ;

c. Menciptakan iklim investasi yang kondusif; isçpip

d. Meningkatkan kepastian hukum terhadap investor asing; iscpi:

e. Mendorong pengembangan ekonomi nasional;

f. Meningkatkan kesejahteraan masyarakat; iscepi

Sebagaimana hal tersebut di atas, tindakan Nasionalisasi ini bertujuan untuk memberi manfaat ekonomi kepada masyarakat Indonesia

${ }_{6}$ Gouw Giok Siong, loc.cit, dikutip dari Wortley, 1980, The Foreign Investment in Indonesia, 1st, Gunung Agung, Singapore, h. 8. 
serta memperkokoh keamanan dan pertahanan negara yang saat itu sedang berkonfrontasi dengan investor asing.

\section{METODE PENELITIAN}

\section{Kerangka Pemikiran}

Penelitian ini termasuk penelitian hukum normatif dengan pendekatan perundang-undangan (statue approach), pendekatan konsep (conceptual approach), pendekatan analisis (analytical approach), dan pendekatan perbandingan (comparative approach). Dengan mulai memaparkan latar belakang permasalahan dalam perspektif problematika filosofis, sosiologis dan yuridis. Dengan menggunakan telaah pustaka yang relevan dengan permasalahan yang diangkat. Selanjutnya dengan menggunakan telaah pustaka dipergunakan asas-asas hukum, teori-teori hukum yang relevan yang ada yang didukung dengan teknis analisis bahan hukum deskripsi (description), interpretasi (interpretation), dan argumentasi (argumentation).

Untuk lebih jelasnya mengenai kerangka berpikir dalam penelitian ini, maka dapat dilihat pada bagan di bawah ini :

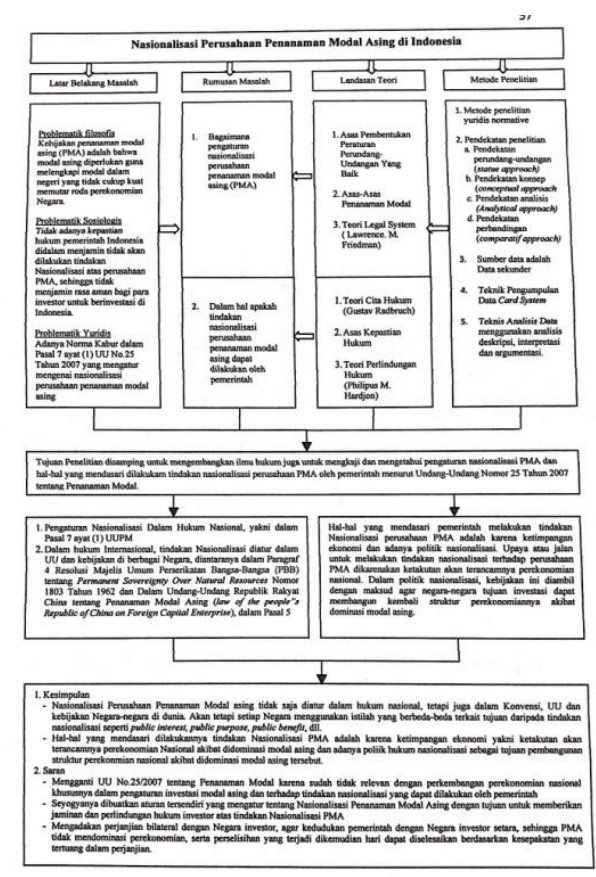

Gambar 1: Kerangka Pemikiran 


\section{Desain Penelitian}

Jenis penelitian adalah yuridis normatif, penelitian hukum dalam hal ini norma kabur (vague van normen) terkait dengan pengaturan nasionalisasi penanaman modal asing, dalam hal apa pemerintah melakukan tindakan nasionalisasi, dan perlindungan hukum terhadap investor terkait nasionalisai penanaman modal asing berdasarkan UndangUndang Nomor 25 Tahun 2007 tentang Penanaman Modal, dengan menggunakan data sekunder yang terdiri dari bahan hukum primer, bahan hukum sekunder dan bahan hukum tertier. Peraturan yang relevan guna membahas dan menganalisis permasalahan yang diangkat dalam tesis ini adalah Undang-undang Nomor 25 Tahun 2007 tentang Penanaman Modal.

Teknik pengumpulan bahan hukum dalam penulisan tesis ini menggunakan teknik sistem kartu (card system) yaitu menelaah peraturanperaturan yang relevan, buku-buku atau bahan-bahan bacaan atau, karya ilmiah para sarjana dan hasilnya dicatat dengan sistem kartu, hal ini dilakukan agar lebih memudahkan dalam penguraian, menganalisa, dan membuat kesimpulan dari konsep yang ada.

Selanjutnya untuk menjawab persoalan dalam penelitian ini, dianalisa dengan proses analisis melalui langkah-langkah deskripsi, interpretasi, dan argumentasi selanjutnya penyimpulan bahan hukum dilakukan dengan cara deduktif yaitu dengan menarik suatu kesimpulan dari data-data yang sifatnya umum ke khusus untuk mendapatkan kejelasan terhadap suatu kebenaran sehingga memperoleh gambaran yang jelas mengenai hal-hal yang melatarbelakangi Pemerintah melakukan tindakan nasionalisasi terhadap perusahaan penanaman modal asing di Indonesia berdasarkan Undang-Undang Nomor 25 Tahun 2007 tentang Penanaman Modal. istepin

Bagian akhir adalah kesimpulan yang merupakan ringkasan pembahasan dari masalah yang diangkat dalam tesis ini, kemudian dilanjutkan dengan memberikan saran dan rekomendasi terkait nasionalisasi perusahaan penanaman modal asing.

\section{Jenis dan Sumber Data}

Penelitian yang dilakukan adalah jenis penelitian yuridis normatif, atau penelitian kepustakaan yang berkaitan dengan substansi hukum yang 
bersifat normatif, di mana penelitian hukum normatif adalah suatu prosedur penelitian ilmiah untuk menemukan kebenaran berdasarkan logika keilmuan dipandang dari sisi normatifnya. ${ }^{7}$ Penelitian hukum normatif adalah penelitian hukum yang dilakukan dengan cara meneliti bahan pustaka atau bahan sekunder belaka. ${ }^{8}$ Untuk menunjang diperolehnya data yang aktual dan akurat, penelitian yang dilakukan bersifat deskriptif yaitu penelitian yang hanya menggambarkan fakta-fakta tentang objek penelitian baik dalam kerangka sistematisasi maupun sinkronisasi berdasarkan aspek yuridis, dengan tujuan menjawab permasalahan yang menjadi objek penelitian. ${ }^{9}$

Sesuai dengan jenisnya, penelitian yuridis normatif merupakan penelitian hukum yang dilakukan dengan cara meneliti bahan pustaka atau data sekunder belaka ${ }^{10}$,yang terdiri dari bahan hukum primen, bahan hukum sekunder dan bahan hukum tertier. Penelitian mengenai nasionalisasi perusahaan penanaman modal asing ini dilakukan dengan menggunakan pendekatan Statute Approach (Pendekatan perundangundangan), Conseptual approach (Pendekatan konsep hukum), dan Comparative Approach (Pendekatan Perbandingan).

\section{Teknik Pengumpulan Data}

Bahan hukum yang relevan dikumpulkan menggunakan teknik sistem kartu (card system), yaitu menelaah peraturan yang relevan, buku /bahan bacaan atau, karya ilmiah para sarjana dan hasilnya dicatat dengan sistem kartu, hal ini dilakukan agar lebih memudahkan dalam penguraian, menganalisa, dan membuat kesimpulan dari konsep yang ada. Studi kepustakaan bertujuan untuk mencapai konsepsi, teori, pendapat ataupun penemuan yang berhubungan erat dengan permasalahan yang diangkat dalam penelitian ini.

7Johny Ibrahim, 2005, Teori dan Metodologi Penelitian Hukum Normatif, Bayu Media Publishing, Surabaya, h. 46.

8 Soerjono Soekanto dan Sri Pamudji, 2013, Penelitian Hukum Normatif Suatu Tinjauan Singkat, PT Raja Grapindo Persada, Jakarta, h.13

9 Bambang Sunggono, 2001, Metodologi Penelitian Hukum, Cetakan Ketiga, Raja Grafindo Persada, Jakarta, h.116-117.

${ }_{10}$ Soerjono Soekanto dan Sri Pamudji, Loc.Cit., 


\section{Teknik Analisis Data}

Setelah langkah pengumpulan bahan hukum dengan sistem kartu lengkap, maka dilanjutkan dengan proses analisis. Analisis dalam penelitian tesis ini menggunakan langkah-langkah Deskripsi (description), Interpretasi (interpretation), dan Argumentasi (argumentation).

Selanjutnya dianalisis dengan menggunakan metode analisis kualitatif didasarkan atas pertimbangan data yang dianalisis diperoleh dari berbagai sumber menyeluruh serta isepimemerlukan informasi yang mendalam.

Selanjutnya untuk menjawab persoalan dalam penelitian ini, metode atau cara penyimpulan bahan hukum dilakukan dengan cara deduktif yaitu dengan menarik suatu kesimpulan dari data-data yang sifatnya umum ke khusus untuk mendapatkan kejelasan terhadap suatu kebenaran sehingga memperoleh gambaran yang jelas mengenai hal-hal yang melatarbelakangi pemerintah melakukan tindakan nasionalisasi terhadap perusahaan penanaman modal asing di Indonesia berdasarkan Undang-Undang Nomor 25 Tahun 2007 tentang Penanaman Modal.

\section{PEMBAHASAN}

\section{Pengaturan Nasionalisasi Dalam Hukum Nasional}

Pengaturan tentang nasionalisasi PMA terdapat dalam salah satu pasal UUPM, dimana klausula nasionalisasi mengakomodasi asas-asas hukum umum yang telah diterima dalam hukum internasional bahwa nasionalisasi harus dilakukan dengan undang-undang disertai pemberian kompensasi.

Tindakan nasionalisasi PMA, ketentuan ini termuat dalam Pasal 7 dan Pasal 8 UUPM, yakni sebagai berikut : ${ }^{11}$

\section{Pasal 7}

(1) Pemerintah tidak akan melakukan tindakan nasionalisasi atau pengambilalihan hak kepemilikan penanam modal, kecuali dengan undang-undang

(2) Dalam hal Pemerintah, melakukan tindakan nasionalisasi atau 
pengambilalihan hak kepemilikan sebagaimana dimaksud dalam ayat (1), Pemerintah akan memberikan kompensasi yang jumlahnya ditetapkan berdasarkan harga pasar.

(3) Jika diantara kedua belah pihak tidak tercapai kesepakatan tentang kompensasi atau ganti rugi sebagaimana ditetapkan dalam ayat (2), penyelesaiannya dilakukan melalui arbitrase.

\section{Pasal 8}

(1) Penanam modal dapat mengalihkan asetnya kepada pihak yang diinginkan penanam modal sesuai dengan ketentuan perundangundangan.

(2) Aset yang tidak termasuk sebagaimana dimaksud dalam ayat 10 merupakan aset yang ditetapkan oleh undang-undang sebagai aset yang dikuasai negara".

Negara dengan kedaulatannya dimungkinkan untuk mengambil alih kepemilikan (ekspropriasi) bahkan bisa menasionalisasi perusahaan dan seluruh aset investor atas nama kepentingan umum. Hal ini sebagaimana terjadi di Indonesia sejak tahun 1956, ketika Pemerintah Republik Indonesia mulai menasionalisasi beberapa perusahaan asing dan berlanjut mencapai puncaknya pada 31 Desember 1958 dengan diundangkannya UU No. 86 tahun 1958 tentang Nasionalisasi Perusahaan Belanda di Indonesia. ${ }^{12}$

Selanjutnya Undang-undang Nomor 68 tahun 1958 tersebut diikuti dengan terbitnya Peraturan Pemerintah Nomor 23 tahun 1958 (PP No. 23/1958) tentang Penempatan Perusahaan Belanda di Bawah Penguasaan Pemerintah Republik Indonesia. Hasilnya 90 persen produk perkebunan beralih ke tangan Pemerintah Indonesia, 90 persen dari perdagangan mancanegara dari Indonesia yang dikuasai Belanda di Indonesia beralih ke pemerintah Indonesia, termasuk 246 pabrik dan perusahaan pertambangan, bank-bank, dan kapal-kapal asing beralih ke Indonesia. ${ }^{13}$

Kemudian diterbitkan Peraturan pemerintah Nomor 3 Tahun 1959 tentang Badan Nasionalisasi Perusahaan Belanda (BANAS) yang harus

12 Rahmi Jened, 2016, Teori dan Kebijakan Hukum Investasi Langsung (Direct Investment), Kencana, Jakarta, h.311

13 Ibid, h.312 
menampung perusahaan-perisahaan Belanda yang dinasionalisasi itu. ${ }^{14}$

\section{Pengaturan Nasionalisasi Dalam Hukum Internasional}

Survei yang dilakukan oleh The Organisation For Economic Cooperation and Development (OECD) menemukan bahwa hukum internasional tidak melarang tindakan nasionalisasi atas modal asing yang dilakukan oleh negara penerima investasi sepanjang memenuhi sejumlah persyaratan. Disebutkan bahwa "customary international law does not preclude hosts states from expropriating foreign investments provided certain condition are met. These conditions are : the taking of the investment for a public purpose, as provided by law, in a non-discriminatory manner with compensation".

Perserikatan Bangsa Bangsa (PBB) nyata-nyata mengakui hak negara tuan rumah, penerima penanaman modal asing untuk melakukan nasionalisasi dengan beberapa persyaratan tertentu. Pengakuan ini merupakan penghormatan terhadap kedaulatan negara yang bersangkutan. Paragraf 4 Resolusi Majelis Umum PBB tentang Kedaulatan Permanen Atas Sumber Daya Alam, Nomor 1803 Tahun 1962 (United Nations General Asembly Resolution on Permanent Sovereignty over Natural Resources).

Undang-undang Republik Rakyat Cina tentang Perusahaan Modal Asing (Law of the People's Republis of China on Foreign Capital Enterprise), yang disahkan oleh Kongres Rakyat Nasional tanggal 12 April 1986 dan kemudian diubah oleh Kongres Rakyat Nasional Pada tanggal 31 Oktober 2000, menyatakan pada Pasal 5 bahwa "the state does not nationalize or requisition any enterprise with foreign capital may be requisitioned through legal procedures and appropriate compensation shall be made".

Keputusan Presiden Filipina sebagaimana tertuang dalam Executive Order No. 226 Tahun 1987, yang dikenal sebagai The Omnibus Investments Code of 1987, memberikan hak-hak dasar dan jaminan berupa perlindungan investasi kepada penanam modal asing pada Pasal 38 butir (d) yang pada intinya menyatakan bahwa pengambilalihan tidak akan

14 Rahmi Jened, 2002, Resume Artikel Karangan Rudi Prasetya dan Neil Hamiton, The Regulation of Indonesian State Enterprises, dalam Tugas Resume mata kuliah Prof.Dr.Rudhi Prasetya, S.H.PJMK Hukum Ekonomi, Program Doktor IImu Hukum Program Pascasarjana Universitas Airlangga, h.6-10 
dilakukan kecuali demi kepentingan umum, demi kesejahteraan rakyat atau untuk kepentingan pertahanan Negara.

Resolusi Mejelis Umum PBB Nomor 3281 Tahun 1974 tentang Charter of Economis Rights and Duties of States mengakui hak setiap Negara untuk secara bebas melaksanakan kedaulatannya, termasuk dalam pemilikan dan penggunaan sumber daya alam dalam kegiatan-kegiatan ekonominya. Pelaksanaan hak ini antara lain mencakup tindakan nasionalisasi. Pasal 2 Ayat 2 huruf c Resolusi ini menyatakan bahwa setiap Negara berhak untuk melakukan nasionalisasi atau ekspropriasi dengan beberapa syarat.

Di tengah kekosongan konvensi Internasional dalam bidang penanaman modal asing, perjanjian investasi bilateral (Bilateral Investment Treaty/BIT) memegang peran penting dalam mengatur masalah penanaman modal lintas Negara. Dalam hubungan dengan nasionalisasi, salah satu tujuan utama BIT adalah untuk melindungi para investor asing dari nasionalisasi yang tidak sah, sewenang-wenang atau diskriminatif yang akan mengurangi minat mereka menanamkan modal di Negara-negara lain. Meskipun kemungkinan bagi nasionalisasi tidak akan pernah tertutup tetapi jika hal itu terjadi akan dilakukan berdasarkan syarat-syarat yang ketat dan fair bagi pemodal asing maupun Negara penerima modal asing. Halmana confirm dengan asas penanaman modal asing yang disebutkan dalam UUPM yang menyebutkan bahwa asas kepastian dalam Negara hukum yang meletakkan hukum dan ketentuan peraturan perundang-undangan sebagai dasar dalam setiap kebijakan dan tindakan dalam bidang penanaman modal dan perlakuan yang sama serta tidak membedakan asal Negara adalah asas perlakuan pelayanan nondiskriminasi berdasarkan ketentuan peraturan perundang-undangan, baik antara penanam modal dalam negeri dan penanam modal asing maupun antara penanam modal dari suatu Negara asing maupun antara penanam modal dari satu Negara asing dan penanam modal dari Negara sing lainnya.

Saat ini, salah satu syarat keabsahan nasionalisasi itu sudah termaktub pada hampir semua perjanjian internasional mengenai investasi, termasuk di dalam BIT banyak Negara. Istilah yang digunakanpun bervariasi, antara lain public purpose, public interest, public benefit, public purpose related to the internal needs dan a purpose which is in the public 
interest.

\section{Hal-Hal Yang Mendasari Dilakukannya Tindakan Nasionalisasi}

Beberapa hal yang mendasari pemerintah melakukan tindakan nasionalisasi perusahaan PMA antara lain :

\section{A. Ketimpangan Ekonomi}

Masa pemerintahan Indonesia di awal tahun 1950-an ditandai dengan adanya ketimpangan antara harapan dengan realita yang dihadapi. Harapan-harapan untuk mewujudkan kedaulatan ekonomi sebagai hasil dari kedaulatan politik yang telah dicapai, tidak dapat diwujudkan dengan segera. Tingkat kesejahteraan penduduk justru merosot. Pada tahun 1951, pendapatan perkapita orang Indonesia sebanyak 28,3 gulden, yang berarti lebih rendah dari pendapatan perkapita pada masa malaise Hindia-Belanda (1930), yaitu sebesar 30 gulden. ${ }^{15}$ Dengan demikian, program pembangunan ekonomi seperti Rencana Urgensi Perekonomian (RUP) dan Program Benteng telah dilaksanakan dalam kondisi ekonomi dengan tingkat kemakmuran yang rendah. Masalah lainnya ialah kurangnya pengalaman dari aparatur negara dalam melaksanakan dan mengawasi rencana tersebut secara birokratis. Meskipun setiap permerintahan yang silih berganti berusaha mewujudkan struktur perekonomian nasional secepatnya, namun jelas pada periode Demokrasi Parlementer jalan perubahan struktur ekonomi lebih bersifat evolusioner ketimbang revolusioner. ${ }^{16}$

Kegagalan dalam upaya untuk mewujudkan ekonomi nasional secepatnya, sebagian besar ditafsirkan oleh para pemimpin Indonesia sebagai kegagalan mengatasi dominasi perusahaan-perusahaan Belanda. Konferensi Meja Bundar yang ditandatangani para pemimpin republik di Den Haag pada tahun 1949 memuat jaminan bahwa hak-hak yang diberikan kepada modal asing akan dihormati. Hal itu berarti bahwa perusahaan-perusahaan Belanda yang berada di Indonesia tetap

15 Sjahrir, 1986, Ekonomi Politik Kebutuhan Pokok, sebuah Tinjauan Prospektif, LP3ES, Jakarta, h.73

16 Budiman Ginting, Agustus 2007, Jurnal Equality, Refleksi Historis Nasionalisasi Perusahaan Asing di Indonesia : Suatu Tantangan Terhadap Kepastian Hukum Atas Kegiatan Investasi di Indonesia, Volume 12, Nomor 2, h. $102-103$ 
mendominasi perekonomian nasional yang bersifat sentral.

Perkembangan ekonomi pasca penyerahan kedaulatan tidak mengalami perubahan dari periode kolonial Hindia-Belanda. Itu berarti perusahaan-perusahaan Belanda tetap mengendalikan sektor perekonomian yang utama. Para pengusaha pribumi hanya bidang industri kerajinan tangan. Sementara industri pengolahan untuk tujuan ekspor dikuasai oleh modal asing, terutama Belanda.

Demikian luasnya bidang usaha yang digeluti oleh perusahaanperusahaan Belanda, maka tidaklah mengherankan bahwa sektor perdagangan besar yang meliputi kegiatan ekspor dan impor hampir seluruhnya mereka kuasai. Sementara dalam bidang perhubungan, sangat sulit bagi perusahaan pelayaran pemerintah PELNI (pelayaran Nasional Indonesia) untuk mengatasi monopoli Koninkljke Paketvaart Maatschappij (KPM), perusahaan pelayaran milik Belanda ${ }^{17}$. Di bidang produksi hasil ekspor terlihat gambaran yang tidak berbeda.

Berdasarkan uraian di atas, tampak hampir semua sektor ekonomi modern di Indonesia sampai akhir tahun 1957 masih terjadi ketimpangan ekonomi yang sebagian besar dimiliki oleh perusahaan Belanda. Ketimpangan ekonomi ini menyebabkan rasa frustasi bagi sebagian besar pemimpin Indonesia. Upaya untuk mewujudkan ekonomi nasional akan selalu terhalang selama modal asing, dalam hal ini Belanda, masih beroperasi di Indonesia. Hal-hal tersebut yang mendasari pemerintah melakukan tindakan Nasionalisasi, dan puncaknya pada 31 Desember 1958 dengan diundangkannya UU No. 86 tahun 1958 tentang Nasionalisasi Perusahaan Belanda di Indonesia.

\section{Politik Hukum Nasionalisasi}

Masalah nasionalisasi ini sangat erat kaitannya dengan kedaulatan Negara. Negara yang berdaulat tentunya menjadi pelindung utama dari kepentingan umum di Negara bersangkutan termasuk kesejahteraannya. Perusahaan-perusahaan asing yang berada di wilayah suatu Negara yang berdaulat dapat saja dinasionalisasi jika kepentingan Negara ini

17 H W Dick, 1990, Industri Pelayaran Indonesia, Kompetisi dan Regulasi, LP3ES, Jakarta, h.24 
menghendakinya.

Secara internasional, hal ini juga telah diakui di dalam resolusi PBB No. 1803/XVII tanggal 14 Desember 1982 dan juga oleh putusan-putusan pengadilan/arbitrase internasional. ${ }^{18}$ Kebijakan pemerintah dalam melakukan tindakan nasionaliasi terhadap perusahaan asing adalah salah satu upaya pemerintah untuk meredam amarah rakyat, dan bertujuan untuk meminimalisir terjadinya kesenjangan ekonomi rakyat. Tindakan nasionalisasi merupakan perbuatan hukum yang bersifat politis yang dalam praktek hukum kenegaraan sering disebut dengan politik hukum. Pemerintah mengambil langkah ini karena memiliki tujuan agar investor asing yang menanamkan modalnya di dalam negeri memiliki batasan, serta pemodal dalam negeri mampu memperbaiki stabilitas perekonomian nasional yang merosot akibat keberadaan penanaman modal asing tersebut. Salah satu jalan keluar yang dipikirkan untuk mengakhiri dominasi perusahaan Belanda ialah dengan jalan melakukan nasionalisasi. Untuk melakukan nasionalisasi dibutuhkan suatu alasan kuat yang dapat dijadikan dasar legitimasi. Terdapat satu isu besar yang menyatukan seluruh pemimpin Indonesia sepanjang dasawarsa 1950-an, yaitu masalah Irian Barat ${ }^{19}$. Hasil Konferensi Meja Bundar tahun 1949 Indonesia mendapat penyerahan kedaulatan dari Belanda.

Target penyelesaian masalah Irian Barat yang ditetapkan KMB, diberi jangka waktu satu tahun, namun ternyata tidak berhasil dicapai. Masalah ini akhirnya berkembang menjadi suatu konfrontasi yang setiap saat berpotensi untuk pecah menjadi konflik terbuka. Untuk mendapat dukungan yang lebih besar, baik Indonesia maupun Belanda kemudian membawa masalah Irian Barat ke tingkat forum internasional. Sebelum pelaksanaan pemungutan suara terhadap resolusi mengenai Irian Barat tersebut, Presiden Sukarno telah memperingatkan bahwa Indonesia akan mengambil langkah- langkah yang akan mengguncang dunia apabila

${ }_{18}$ Sudargo Gautama, 1986, Indonesia dan Arbitrase Internasional, Alumni, Bandung, h. 50

19 Andrey R Kahin \& George McT Kahin, 1997, Subversi Sebagai Politik Luar Negeri Menyingkap Keterlibatan CIA di Indonesia, Pustaka Utama Grafiti, Jakarta, h.56 
resolusi tersebut gagal ${ }^{20}$. Ternyata Presiden Sukarno tidak hanya menggertak saja. Pada tanggal 1 Desember 1957 permerintah Indonesia secara resmi mengumumkan aksi mogok selama 24 jam terhadap perusahaan-perusahaan Belanda di Indonesia ${ }^{21}$. Tindakan inilah yang mengawali aksi nasionalisasi perusahaan-perusahaan Belanda secara besar-besaran.

\section{Jaminan Terhadap Tindakan Nasionalisasi Perusahaan Penanaman Modal Asing (PMA)}

Adanya ketentuan dalam UUPM dan pengalaman nasionalisasi yang pernah dilakukan Indonesia, maka pada masa yang akan datang diperkirakan Indonesia tidak akan melakukan nasionalisasi perusahaanperusahaan asing, berdasarkan alasan-alasan berikut ini :22

1. Sejak pemerintahan Indonesia membuka diri kepada modal asing dengan lahirnya Undang-Undang Nomor 1 Tahun 1967 tentang Penanaman Modal Asing yang telah digantikan oleh UUPM, tidak ada indikasi atau tanda-tanda pemerintah berencana melakukan nasionalisasi;

2. Keadaan sosial ekonomi Indonesia masih memiliki besarnya pengangguran dan kerusakan infrastruktur seperti jalan, pelabuhan, pembangkit tenaga listrik, penggalian sumber-sumber daya alam baru, memerlukan modal asing yang tidak sedikit;

3. Keanggotaan Indonesia dalam organisasi perdagangan international dan perjanjian bilateral mengenai promosi dan perlindungan penanaman modal dengan berbagai Negara, membuat tipis kemungkinan pemerintah Indonesia akan melakukan nasionalisasi perusahaan asing. Selain itu, Indonesia juga telah menandatangani perjanjian keamanan berinvestasi dengan 60 negara.

Praktik perlindungan investasi berupa jaminan tidak ada

20 Howard Palfrey Jones, 1980, Indonesia : The Possible Dream, Brace Javanovis, New York, h.184-185

21 Anderson G Bartlett, et all, 1986, Pertamina : Indonesian National Oil, Tulsa: Amerasian Ltd, Singapore, Jakarta, h.100

22 Suparji, Penggturan Penanaman Modal di Indonesia, Universitas Al Azhar Indonesia, h. 90 
nasionalisasi merupakan praktik internasional. Syarat-syarat untuk melakukan nasionalisasi yang berlaku secara internasional sangat ketat, yaitu harus dilakukan melalui suatu undang-undang, harus ada kompensasi terhadap perusahaan yang dinasionalisasi sesuai dengan harga pasar dan nasionalisasi tidak boleh didasarkan pada alasan politis, tetapi sematamata alasan ekonomis. ${ }^{23}$

\section{Perlindungan Hukum Investor Atas Tindakan Nasionalisasi Oleh Pemerintah}

Menurut Philipus M. Hadjon dibedakan 2 (dua) macam perlindungan hukum yaitu : perlindungan hukum yang preventif dan perlindungan hukum yang represif. Perlindungan hukum terhadap investor dititikberatkan pada perlindungan preventif, dimana diberikan kesempatan bagi investor untuk merngajukan keberatan (inspraak) atau pendapatnya sebelum suatu keputusan pemerintah mendapat bentuk yang definitif terkait tindakan nasionalisasi atas perusahaan PMA. Dengan demikian, perlindungan hukum yang preventif bertujuan untuk mencegah terjadinya sengketa. Perlindungan hukum preventif sangat besar artinya bagi tindakan pemerintah yang didasarkan kepada kebebasan bertindak karena dengan adanya perlindungan hukum yang preventif pemerintah terdorong untuk bersikap hati-hati dalam mengambil keputusan pengambilalihan atau nasionalisasi perusahaan PMA yang didasarkan pada diskresi. ${ }^{24}$

Perlindungan hukum yang diberikan oleh pemerintah Indonesia untuk lebih meningkatkan kepercayaan investor asing dalam menanamkan modalnya, salah satunya membuat perjanjian bilateral dengan berbagai negara asal investor, perjanjian investasi ini melahirkan beberapa prinsip yang umum berlaku dalam tata pergaulan internasional. Prinsip tersebut antara lain : prinsip A national treatment clause, artinya setiap pihak akan memberikan perlakuan yang sama bagi para pihak yaitu pihak tuan rumah dan pihak penanam modal. Kedua, prinsip $A$ most favoured nation clause, artinya pihak tuan rumah ataupun pihak penanaman modal asing, tidak

23 Kaj Hober, 2003, Investment Arbitration In Eastern Europe: Recent Cases On Expropriation", American Review of International Arbitration, Vol. 14, h. 383-384

24 Philipus M. Hadjon, 1987, Perlindungan Hukum Bagi Rakyat di Indonesia, PT Bina IImu, Surabaya, h.3 
akan mendapatkan perlakuan yang kurang dibandingkan dengan pihak lain. ${ }^{25}$

Tindakan pemerintah Indonesia lainnya yaitu meratifikasi konvensi The Convensional Establishing the Multilateral Investment Guarantee (MIGA), berdasarkan Keputusan Presiden Nomor 1 Tahun 1986. Hal tersebut memberikan pandangan positif kepada Indonesia oleh pihak penanam modal asing, karena dengan hal tersebut pihak Indonesia telah memberikan suatu jaminan perlindungan hukum bagi pihak penanam modal asing atas resiko penanaman modal asing di Indonesia. Selain itu dengan diterbitkannya Undang-undang No. 25 Tahun 2007 telah memberikan suatu jaminan atas perlindungan dan kepastian hukum bagi para penanam modal terhadap pengambilalihan atas perusahaan asing yang tertera dalam Pasal 7 UUPM.

\section{PENUTUP}

\section{Simpulan}

1. Pengaturan Nasionalisasi perusahaan penanaman modal asing baik dalam hukum nasional maupun internasional diwujudkan melalui :

A. Nasionalisasi Menurut Undang-Undang Nomor 25 Tahun 2007 tentang Penanaman Modal (UUPM). Pengaturan tindakan Nasionalisasi PMA dalam UUPM termuat dalam pasal yakni Pasal 7 dan Pasal 8. Klausula Nasionalisasi mengakomodasi asas-asas hukum umum yang telah diterima dalam hukum internasional bahwa nasionalisasi harus dilakukan dengan Undang-Undang (Pasal 7 ayat (1) dan disertai pemberian kompensasi (Pasal 7 ayat (2).

B. Nasionalisasi Dalam Hukum Internasional

1. Persetujuan bilateral, seperti dalam Bilateral Investment Treaty antara Pemerintah Republik Indonesia dan Pemerintah Kerajaan Inggris;

2. Persetujuan multilateral, seperti pengesahan Washington Convention 1965 dan New York Convention 1958.

3. Dalam Paragraf 4 Resolusi Majelis Umum Perserikatan Bangsah.233.

25 Sentosa Sembiring, 2007, Hukum Investasi, Nuansa Aulia, Bandung, 
Bangsa (PBB) tentang Permanent Sovereignty Over Natural Resources (Kedaulatan Permanen Atas Sumber Daya Alam), Nomor 1803 Tahun 1962 menyatakan bahwa PBB nyata-nyata mengakui hak negara tuan rumah sebagai penerima modal asing untuk melakukan tindakan nasionalisasi dengan beberapa persyaratan tertentu, pengakuan ini merupakan penghormatan bagi kedaulatan negara yang bersangkutan;

4. Dalam Undang-Undang Republik Rakyat China tentang Penanaman Modal Asing (law of the people"s Republic of China on Foreign Capital Enterprise), dalam Pasal 5 dinyatakan bahwa Negara tidak menasionalisasi atau meminta perusahaan apapun dalam modal asing, bilamana diminta harus sesuai dengan prosedur hukum dan kompensasi yang sesuai harus dilakukan;

5. Keputusan Presiden Filipina (Executive Order Nomor 226 Tahun 1987) atau dikenal dengan The Omnibus Investment Code 1987, dalam Pasal 38 butir (d) menyatakan bahwa pengambilalihan tidak akan dilakukan kecuali untuk kepentingan umum, kesejahteraan rakyat atau kepentingan negara;

6. Resolusi Majelis Umum Perserikatan Bangsa-Bangsa (PBB) Nomor 3281 Tahun 1974 tentang Charter of Economics Rights and Duties of States, dalam Pasal 2 ayat (2) huruf c menyatakan bahwa setiap negara berhak untuk melakukan nasionalisasi atau ekspropriasi dengan beberapa syarat;

Saat ini salah satu syarat keabsahan nasionalisasi itu sudah termaktub pada hampir semua perjanjian internasional mengenai investasi. Akan tetapi setiap Negara menggunakan istilah yang berbeda-beda terkait tujuan daripada tindakan nasionalisasi seperti public interest, public purpose, public benefit, dll.

2. Hal-hal yang mendasari pemerintah melakukan tindakan Nasionalisasi perusahaan PMA adalah karena ketimpangan ekonomi dan adanya politik nasionalisasi. Upaya atau jalan untuk melakukan tindakan nasionalisasi terhadap perusahaan PMA dikarenakan ketakutan akan terancamnya perekonomian nasional. Dalam politik nasionalisasi, tindakan nasionalisasi merupakan perbuatan hukum yang bersifat politis 
yang dalam praktek hukum kenegaraan sering disebut dengan politik hukum. Pemerintah mengambil langkah ini karena memiliki tujuan agar investor asing yang menanamkan modalnya di dalam negeri memiliki batasan, serta pemodal dalam negeri mampu memperbaiki stabilitas perekonomian nasional yang merosot akibat keberadaan penanaman modal asing tersebut.

\section{Saran}

1. Mengganti Undang-Undang Nomor 25 Tahun 2007 tentang Penanaman Modal karena sudah tidak relevan dengan perkembangan perekonomian nasional khususnya dalam pengaturan investasi modal asing serta tindakan nasionalisasi yang dapat dilakukan oleh pemerintah bilamana modal asing mendominasi dan mengancam perekonomian nasional.

2. Seyogyanya dibuatkan aturan terkait masalah nasionalisasi terhadap perusahaan penananam modal asing di Indonesia ini dalam UndangUndang tersendiri agar tercapainya "Mutual Benefits"secara lebih spesifik atau lex specialist, dan mengatur secara tegas mengenai hal-hal yang mendasari tindakan nasionalisasi tehadap PMA di Indonesia, dan diatur secara eksplisit terhadap jaminan dan perlindungan investor atas tindakan nasionalisasi perusahaan penanaman modal asing.

3. Mengadakan perjanjian Bilateral dengan Negara-Negara yang akan menginvestasikan modalnya di dalam negeri, hal ini bertujuan agar pihak pemerintah Indonesia sebagai Negara tuan rumah atau penerima modal memiliki kedudukan yang setara dengan Negara pemberi modal (investor) sehingga penanaman modal asing tidak mendominasi perekonomian serta segala bentuk konflik, perselisihan yang terjadi dikemudian hari dapat diselesaikan berdasarkan kesepakatan yang disebutkan dalam perjanjian tanpa adanya intervensi unsur politis antara pihak penerima modal dengan penanam modal asing. Hal mana perjanjian yang dibuat berlaku sebagai Undang-Undang bagi para pihak (pacta sunt servanda), mengikat dan tidak boleh bertindak di luar daripada yang diperjanjikan; 


\section{DAFTAR PUSTAKA}

\section{Buku:}

Bartlet, G. Anderson, et all.,1986, Pertamina : Indonesian National Oil, Tulsa, Amerasian Ltd, Singapore, Jakarta

Dick. H.W.,1990, Industri Pelayaran Indonesia, Kompetisi dan Regulasi, LP3ES, Jakarta

George, Margareth, 1986, Australia dan Revolusi Indonesia, PT Pantji Simpati, Jakarta

Gautama, Sudargo, 1986, Indonesia dan Arbitrase Internasional, Alumni, Bandung

George, McT.Kahin \& Andrey R.Kahin.,1997, Subversi Sebagai Politik Luar Negeri Menyingkap Keterlibatan CIA di Indonesia, Pustaka Utama Grafiti, Jakarta

Hadjon, M.Philipus.,1987, Perlindungan Hukum Bagi Rakyat di Indonesia, PT Bina IImu, Surabaya

Johny Ibrahim, 2005, Teori dan Metodologi Penelitian Hukum Normatif, Bayu Media Publishing, Surabaya

Jened, Rahmi, 2016, Teori dan kebijakan Investasi Langsung (Direct Investment), Kencana, Jakarta

Sjahrir, 1986, Ekonomi Politik Kebutuhan Pokok, sebuah Tinjauan Prospektif, LP3ES, Jakarta.

Sembiring, Sentosa, 2010, Hukum Investasi, Nuansa Aulia, Bandung

Soekanto, Soerjono, dan Sri Mamudji, 2015, Penelitian Hukum Normatif (suatu tinjauan singkat), PT. Rajagrafindo Persada, Jakarta

Suparji, Penggauran Penanaman Modal di Indonesia, Universitas Al Azhar Indonesia.

Sinamo, Nomensen, 2016, IImu Perundang-Undangan, Jala Permata Aksara, Jakarta

\section{Peraturan Perundang-Undangan:}

Undang-Undang Dasar Negara Republik Indonesia Tahun 1945

Peraturan Pemerintah Pengganti Undang-Undang Nomor 23 Tahun 1959 tentang Pencabutan Undang-Undang No. 74 Tahun 1957 (Lembaran Negara No. 160 Tahun 1957) Dan Penetapan Keadaan Bahaya, Lembaran Negara Republik Indonesia Tahun 1959 Nomor 139. 
Undang-Undang Nomor 12 Tahun 2011 tentang Pembentukan Peraturan Perundang-Undangan, Lembaran Negara Republik Indonesia Tahun 2011 Nomor 82

\section{Sumber Dari Jurnal IImiah Hukum:}

Ginting, Budiman Agustus 2007, Jurnal Equality, Refleksi Historis Nasionalisasi Perusahaan Asing di Indonesia : Suatu Tantangan Terhadap Kepastian Hukum Atas Kegiatan Investasi di Indonesia, Volume 12, Nomor 2

Hober, Kaj 2003, Investment Arbitration In Eastern Europe: Recent Cases On Expropriation", American Review of International Arbitration, Vol. 14 , h. $383-384$

Yulianto, Ahmad, 2003, Peranan Multilateral Investment Guarantee Agency (MIGA) Dalam Kegiatan Investasi, Jurnal Hukum Bisnis, Vol.22, No. 5

Kairandy, Ridwan, 2003, Peranan Perusahaan Penanaman Modal Asing Joint Venture Dalam Alih Teknologi d Indonesia, Jurnal Hukum Bisnis, Vol.22, No. 5

Syahyu, Yulianto, 2003, Pertumbuhan Investasi Asing di Kepulauan Batam: Antara Dualisme Kepemimpinan dan Ketidakpastian Hukum, Jurnal Hukum Bisnis, Vol.22, No. 5

\section{Artikel Internet:}

Rahmi Jened, 2002, Resume Artikel Karangan Rudi Prasetya dan Neil Hamiton, The Regulation of Indonesian State Enterprises, dalam Tugas Resume mata kuliah Prof.Dr.Rudhi Prasetya, S.H.PJMK Hukum Ekonomi, Program Doktor IImu Hukum Program Pascasarjana Universitas Airlangga Investopedia, "Nationalization", URL:http://www.investopedia.com/terms/n/nationalization.asp, diakses pada tanggal 16 Agustus 2017. 